\title{
A cross sectional study of salt content in bakery bread in Zagreb, Croatia
}

\author{
Marija Delaš Aždajić1,2, Ivančica Delaš $\breve{3}^{3}$, Stjepan Aždajić2 ${ }^{2}$ Danijela Štimac Grbić3 ${ }^{3,4}$, and \\ Nada Vahčić ${ }^{1}$ \\ ${ }^{1}$ Faculty of Food Technology and Biotechnology, University of Zagreb, Pierottijeva 6, Zagreb, Croatia \\ ${ }^{2}$ Sestre Milosrdnice University Hospital Center, Vinogradska cesta 29, Zagreb, Croatia \\ ${ }^{3}$ School of Medicine, University of Zagreb, Šalata 3, Zagreb, Croatia \\ ${ }^{4}$ Croatian Institute of Public Health, Rockefellerova ulica 12, Zagreb, Croatia
}

[Received in March 2019; Similarity Check in March 2019; Accepted in September 2019]

Reducing salt content in bread is the essential part of a national strategy for salt reduction with the goal of long-term national general health improvement. In this study we have analysed salt content in three types of bread available in 25 small and five national industrial bakeries in Zagreb, Croatia. Samples of white wheat bread, dark wheat bread, and other types of bread were collected, and the salt content was determined with the Mohr method. Salt content varied widely between bakeries, with an average content of $2.30 \pm 0.22 \mathrm{~g}$ per $100 \mathrm{~g}$ of bread, which is almost twice the threshold content $(1.4 \%)$ defined by the Croatian National Regulation on Cereals and Cereal Products. Further efforts are necessary to teach bakers how to reduce salt content without affecting quality or flavour. These should go hand in hand with continuous monitoring of how the legal provisions are implemented.

KEY WORDS: hypertension; Mohr method; sodium chloride

High intake of sodium and low intake of whole grains and fruits are the leading dietary risk factors for deaths and disability-adjusted life-years (DALYs) in many countries (1). Several studies have shown that high levels of sodium and low levels of potassium increase the risk of arterial hypertension and, consequently, of cardiovascular diseases (CVDs) $(2,3)$. Sodium restriction in infancy is supposed to have positive effects on lowering blood pressure both in childhood and adulthood(4). CVDs are the leading cause of death in the world (5) and Croatia, where the death rate has reached $5.70 \%$, and $37 \%$ of population suffers from high blood pressure $(6,7)$.

According to the World Health Organization (WHO) recommendations (8), the daily intake of sodium and salt in adults should be less than 2 and $5 \mathrm{~g}$, respectively. Considering the average daily intake of salt in Europe, Croatia ranks the third top consumer (after Turkey and Hungary) with an average of 13-16 g (9).

The major sources of sodium in human diet are industrial products ( $77 \%$ ), sodium naturally present in food $(12 \%)$, salt added during food preparation $(5 \%)$, and salt added during food consumption $(6 \%)(7)$.

Bread and other bakery products are staple food in traditional Mediterranean diets (10), including Croatian.

Corresponding author: Marija Delaš Aždajić, MD, MSc HCM, BNutr, Department of Dermatology and Venereology, Sestre Milosrdnice University Hospital Center, Vinogradska cesta 29, 10000 Zagreb, Croatia

E-mail:marija.delas.azdajic@kbcsm.hr
Perl Pirički et al. (11) reported that Croats consumed an average of $117.7 \pm 78.3 \mathrm{~g}$ of bread per day, while a more recent study (12) reported annual consumption of $80 \mathrm{~kg}$ of bread per capita. An estimated amount of salt added to bakery products in Croatia is $\sim 2 \%$, and the average daily intake of salt through bakery products is estimated at 25$30 \%(13-15)$. A recent study by Pucarin-Cvetković et al. (16) reported an average daily intake of sodium in Croatia of $11.6 \mathrm{~g}$ (13.3 $\mathrm{g}$ for men and $10.2 \mathrm{~g}$ for women), which is almost double the WHO recommendation. The same study established that the mean 24-hour natriuresis was higher in rural than in urban residents.

However, there is no up to date information about salt content in bread and total daily salt intake that could help Croatian health policy makers review their current policies and come up with action plans. The aim of our study was to extend and update our preliminary findings, published in Croatian in 2018 (13) about salt content in bakery bread available in the Croatian capital and largest city, Zagreb.

\section{MATERIALS AND METHODS}

\section{Sample collection}

Bakeries for sample collection were selected from the official database of Zagreb bakeries registered with the Croatian Chamber of Commerce. Of 263 of them, we 
randomly selected five small bakeries from each part of Zagreb (north, south, east, west, and centre) and also included five leading industrial producers of bakery products with shops all over the city (and the nation). In total, the study included 30 bakeries.

Bread samples included three types of bread: white wheat bread, dark wheat bread, and mixed bread made with the flour of other cereals (rye, corn, mixed cereals, special bread and others).

All samples were collected within one week, in the morning hours and analysed on the same day.

\section{Sample preparation}

Bread samples were sliced, cut into smaller pieces, and dried to constant mass in a dry heat steriliser (model ST$01 / 02$, Instrumentaria, Zagreb, Croatia) at $105 \pm 2{ }^{\circ} \mathrm{C}$. Dried samples were then cooled, crushed and $5 \mathrm{~g} \pm 0.1 \mathrm{mg}$, placed in a $100 \mathrm{~mL}$ glass beaker, and quantitatively transferred with water to a $100 \mathrm{~mL}$ volumetric flask. The content was shaken, allowed to stand for $15 \mathrm{~min}$, and filtered through a wrinkled filter paper.

\section{Salt determination}

Salt was determined with the Mohr method for the analysis of $\mathrm{Cl}^{-}$and $\mathrm{Br}$ ions using $\mathrm{AgNO}_{3}$ solution in neutral or low alkaline media (17). Each titration was done in triplicate.

The amount of sodium chloride in the analysed samples was calculated and salt content expressed as $\mathrm{g} / 100 \mathrm{~g}$ of bread $(\%)$.

\section{Statistical analysis}

Data were analysed with the Statistical Package for the Social Sciences (SPSS) program version 23.0 (IBM Corporation, Armonk, NY, United States). In addition to descriptive statistics, one-way and two-way analysis of variance and $t$-test were ran to establish differences between the types of bread and the position and types of the bakeries. Significance was set at $\mathrm{P}<0.05$.

\section{RESULTS}

The average salt content in the collected samples was $2.30 \pm 0.22 \mathrm{~g}$ per $100 \mathrm{~g}$ of bread (Table 1$)$ - almost twice the amount defined by the Croatian Regulation of Cereals and Cereal Products $(<1.4 \%)$ (18) for baked bread. In fact, all but one bread sample (1.19 g per $100 \mathrm{~g}$, see Table 1) exceeded the Regulation provision.

The highest average salt content in white wheat bread was $2.39 \mathrm{~g}$ per $100 \mathrm{~g}$ and in dark wheat bread $2.81 \mathrm{~g}$ per $100 \mathrm{~g}$, while in samples of other types of bread, the highest salt content was $2.52 \mathrm{~g}$ per $100 \mathrm{~g}$.

Significant differences ( $t$-test) were established between white wheat bread and other types of bread $(\mathrm{P}<0.018)$.
ANOVA confirmed significant difference between bread types $(\mathrm{P}=0.027)$, but there was no significant difference between locations $(\mathrm{P}=0.459$ for white bread, $\mathrm{P}=0.624$ for dark wheat bread, and $\mathrm{P}=0.827$ for other types of bread).

\section{DISCUSSION}

A 2009 salt analysis in bread from Croatian bakeries (14) reported an average of $5 \mathrm{~g}$ of sodium per kilogram of bread. The amount of salt used during dough preparation varied a lot, and it was not possible to calculate the absolute amount of salt in bread on the national level.

For comparison, a Mozambique study reported mean sodium content of $0.45 \mathrm{~g}$ per $100 \mathrm{~g}$ of bread $(1.14 \%$ calculated on salt) (19), and a Peru study reported $1.2 \mathrm{~g}$ of salt per $100 \mathrm{~g}$ of bread (20). In Bosnia and Herzegovina salt content was reported to range between 1.3 and $2.0 \mathrm{~g}$ per $100 \mathrm{~g}$ of bread (21) and in Serbia between 1.1 and $2.4 \mathrm{~g}$ per $100 \mathrm{~g}$ of white bread (22).

The association between sodium intake and blood pressure has already been well established and its reduction is perceived as a way to reduce blood pressure. According to a 2019 Eurobarometer special survey, $24 \%$ of respondents from $27 \mathrm{EU}$ countries claimed to "avoid / not eat too much salt" (23). However, reducing salt intake is a long-term process. In 2008, the European Union developed the Framework on voluntary national salt initiatives (24), which set a benchmark of minimum $16 \%$ salt reduction over four years for all food products (25). A survey on the Framework's implementation in the member states from mid-2008 to mid-2012 (25) showed that bread, cereals, and bakery products were the most important sources of salt in most national diets, with bread contribution of around $20 \%$ or more of the total salt intake. The regions with the highest reported salt intake levels were East and South Europe.

Of all public health interventions into a daily diet, salt reduction seems to be one of the easiest to implement. However, its full implementation should involve interdisciplinary collaboration, especially with food industry (26).

The WHO's Global Action Plan for the Prevention and Control of Noncommunicable Diseases for 2013-2020 (27), in turn, set the relative salt reduction target to $30 \%$. In line with these trends, in September 2014, the Croatian government issued a Strategic Plan for Reduction of Salt Intake $20 \%$ (from $11.6 \mathrm{~g}$ per day to $9.3 \mathrm{~g}$ per day) between 2015 and 2019 (28).

However, all these action plans and targets need full collaboration with all the stakeholders, food industry in particular (26). Some progress in dietary sodium reduction through population-level government initiatives was reported by Cochrane in 2016 (29) for several high-income countries, but the level of evidence was low. Reportedly, United Kingdom achieved significant reduction thanks to pricing interventions and nutrition policies (including on- 
Table 1 Salt content in bread samples $(\mathrm{n}=90)$ collected from bakeries across Zagreb

\begin{tabular}{|c|c|c|c|c|c|c|}
\hline \multirow[b]{2}{*}{ Type of bakery } & \multirow{2}{*}{$\begin{array}{l}\text { Location in } \\
\text { the city }\end{array}$} & \multirow[b]{2}{*}{ Type of bread } & \multicolumn{4}{|c|}{ Statistical parameters } \\
\hline & & & $\begin{array}{c}\text { Mean } \\
\text { (g/100 } \mathrm{g} \text { of bread) }\end{array}$ & SD & $\begin{array}{c}\text { Range } \\
\text { (g/100 g of bread) }\end{array}$ & $\mathrm{CV}$ \\
\hline \multirow{15}{*}{ Small bakeries } & \multirow{3}{*}{ North } & White wheat bread & 2.01 & 0.16 & $1.43-2.32$ & 8.11 \\
\hline & & Dark wheat bread & 2.62 & 0.43 & $1.66-3.78$ & 16.29 \\
\hline & & Other types of bread & 2.31 & 0.16 & $1.94-2.87$ & 6.82 \\
\hline & \multirow{3}{*}{ South } & White wheat bread & 2.30 & 0.14 & $1.96-2.78$ & 6.02 \\
\hline & & Dark wheat bread & 2.11 & 0.18 & $1.43-2.39$ & 8.33 \\
\hline & & Other types of bread & 2.31 & 0.16 & $1.80-2.68$ & 7.04 \\
\hline & \multirow{3}{*}{ East } & White wheat bread & 2.14 & 0.18 & $1.70-2.66$ & 8.46 \\
\hline & & Dark wheat bread & 2.81 & 0.46 & $1.19-3.57$ & 16.40 \\
\hline & & Other types of bread & 2.52 & 0.22 & $1.67-2.84$ & 8.66 \\
\hline & \multirow{3}{*}{ West } & White wheat bread & 2.39 & 0.16 & $2.12-2.97$ & 6.59 \\
\hline & & Dark wheat bread & 2.56 & 0.17 & $2.13-3.13$ & 6.47 \\
\hline & & Other types of bread & 2.50 & 0.24 & $1.80-3.08$ & 9.75 \\
\hline & \multirow{3}{*}{ Center } & White wheat bread & 2.29 & 0.14 & $2.03-2.76$ & 5.90 \\
\hline & & Dark wheat bread & 2.47 & 0.25 & $1.89-3.38$ & 10.05 \\
\hline & & Other types of bread & 2.24 & 0.25 & $1.51-3.04$ & 11.30 \\
\hline \multirow{3}{*}{ Small bakeries } & \multirow{3}{*}{ All } & White wheat bread & $2.23^{\mathrm{a}}$ & 0.07 & $2.01-2.39$ & 3.02 \\
\hline & & Dark wheat bread & 2.51 & 0.12 & $2.11-2.81$ & 4.59 \\
\hline & & Other types of bread & $2.38^{\mathrm{c}}$ & 0.06 & $2.24-2.52$ & 2.37 \\
\hline \multirow{3}{*}{ Industrial bakeries } & \multirow{3}{*}{ All } & White wheat bread & $2.00^{\mathrm{b}}$ & 0.03 & $1.87-2.05$ & 1.67 \\
\hline & & Dark wheat bread & 2.56 & 0.09 & $2.32-2.84$ & 3.66 \\
\hline & & Other types of bread & $2.14^{\mathrm{d}}$ & 0.06 & $2.00-2.30$ & 2.62 \\
\hline TOTAL (all bakerie & & & 2.30 & 0.22 & $1.19-3.78$ & 9.48 \\
\hline
\end{tabular}

$\overline{\mathrm{SD}}=$ standard deviation; $\mathrm{CV}=$ coefficient of variation; ${ }^{\mathrm{a}, \mathrm{b}, \mathrm{c}, \mathrm{d}}$ Mean values within a column with different superscript letters were significantly different $(\mathrm{P}<0.05)$

package nutrition information, restrictions on marketing to children, and food product reformulation).

But most remarkable was the success of public health interventions in Finland, as they have shown that it is possible to change behavioural and nutritional habits (30). Through community-based collaboration with the food industry between 1979 and 2002, urinary sodium excretion dropped from 220 to $170 \mathrm{mmol} / \mathrm{L} /$ day among Finnish men and from 180 to $130 \mathrm{mmol} / \mathrm{L} /$ day among Finnish women.

In most high-income countries packaged and ultraprocessed food contribute with most sugar and sodium consumed in daily diet $(31,32)$. Food reformulation was reported to reduce as much as $67 \%$ of sodium in bread without affecting bread consumption when potassium chloride and yeast extract replaced it to make up for the loss of flavour(33). In a study from New Zealand (34), the replacement of sodium with potassium and magnesium salts gained 294,000 quality-adjusted life-years (QALYs) over the remaining lifetime, along with the net cost-savings of NZ\$ 1.5 billion. One Croatian study (35) reported that up to $25 \%$ salt reduction did not significantly affect the technological process of bread production (gluten development, rheology properties of dough and fermentation speed) or its quality. These results are in line with a recent Peruvian study (20).

Croatia has recognised the importance of establishing a rewarding programme for producers whose food meets clearly defined nutritional criteria. Since June 2015, its national programme "Healthy Living" has been implemented to reduce behavioural, biomedical, and socio-medical risks of noncommunicable diseases (36).

\section{CONCLUSION}

Bread salt content in Zagreb still exceeds the recommended threshold of the Croatian National Regulation on Cereals and Cereal Products, and health authorities. Further efforts are necessary to teach bakers how to reduce salt content without affecting the flavour and quality of their products. In addition, consumers should be more vigorously advised to reduce consumption of products with high salt content.

The main shortcoming of this study is the small sample size. Future studies should include more bakeries and all parts of Croatia to get a better insight into salt use in these products. Additionally, they should include information 
about the amounts of bread and bakery products consumed by the population in order to estimate total salt consumption through this type of food.

\section{REFERENCES}

1. GBD 2017 Diet Collaborators. Health effects of dietary risks in 195 countries, 1990-2017: a systematic analysis for the Global Burden of Disease Study 2017. Lancet 2019;393:1958 72. doi: 10.1016/S0140-6736(19)30041-8

2. Thout SR, Santos JA, McKenzie B, Trieu K, Johnson C, McLean R, Arcand J, Campbell NRC, Webster J. The Science of Salt: Updating the evidence on global estimates of salt intake. J Clin Hypertens (Greenwich) 2019;21:710-21. doi: 10.1111/jch.13546

3. Al Jawaldeh A, Rafii B, Nasreddine L. Salt intake reduction strategies in the Eastern Mediterranean Region. East Mediterr Health J 2019;24:1172-80. doi: 10.26719/emhj.18.006

4. Appel LJ, Lichtenstein AH, Callahan EA, Sinaiko A, Van Horn L, Whitsel L. Reducing sodium intake in children: A public health investment. J Clin Hypertens (Greenwich). 2015;17:657-62. doi: 10.1111/jch.12615

5. World Health Organization (WHO). Diet, Nutrition and the Prevention of Chronic Diseases. Report of a Joint WHO/FAO Expert Consultation. WHO Technical Report Series, no. 916, Geneva 2003 [displayed 20 April 2017]. Available at https:// apps.who.int/iris/bitstream/handle/10665/42665/WHO TRS $916 . p d f ; j$ s es sionid=F 639 B 3 E 5 A 0 DDD0C89E60FBF32D5E3936? sequence $=1$

6. Croatian Institute of Public Health (CIPH). Croatian Health Statistics Yearbook 2017. Zagreb, Croatia [displayed 04 December 2018]. Available at https://www.hzjz.hr/en/otherpublications/croatian-health-statistics-yearbook-2017/

7. Pucarin Cvetković J. Sol u prehrani - čimbenik rizika od razvoja kroničnih nezaraznih bolesti. [Salt in nutrition - risk factor for the noncommunicable diseases development, in Croatian]. In: Šatalić Z, editor. [100 (i pokoja više) crtica iz znanosti o prehrani, in Croatian]. $1^{\text {st }}$ ed. Croatian Zagreb: Society of Food Technologists, Biotechnologists and Nutritionists; 2013. p. 184-5.

8. World Health Organization (WHO). Guideline: Sodium intake for adults and children [displayed 04 November 2018]. Available at http://www.who.int/nutrition/publications/ guidelines/sodium_intake_printversion.pdf

9. World Health Organization (WHO). Mapping salt reduction initiatives in the WHO European Region [displayed 14 July 2018]. Available at http://www.euro.who.int/ data/assets/ pdf_file/0009/186462/Mapping-salt-reduction-initiatives-inthe-WHO-European-Region.pdf

10. Quilez J, Salas-Salvado J. The feasibility and acceptability of reducing salt in partially baked bread: A Spanish case study. Public Health Nutr 2016;19(Suppl 6):983-7. doi: 10.1017/S1368980015000944

11. Perl Pirički A, Kenjerić D, Mandić ML. Cereals as source of vitamins and minerals, In: Ugarčić-Hardi Ž, editor. Proceedings of $4^{\text {th }}$ International Congress Flour-Bread'07, $6^{\text {th }}$ Croatian Congress of Cereal Technologists; 24-27 October 2007; Opatija, Croatia. Osijek: Faculty of Food Technology J.J. Strossmayer University of Osijek; 2008. p. 466-70.

12. Ćurić D, Ugarčić Ž, Novotni D, Koceva Komlenić D, Jukić M. [Stanje u mlinskoj, pekarskoj i tjesteničarskoj industriji te perspektive razvoja tih vrsta industrije, in Croatian]. In: Matić S, Tomić F, Anić I, editors. [Proizvodnja hrane i šumarstvo - temelj razvoja istočne Hrvatske: u povodu 20. obljetnice utemeljenja Znanstvenog vijeća za poljoprivredu i šumarstvo, in Croatian]. Zagreb: Croatian Academy of Sciences and Arts; 2013. Book of abstracts p. 30-1.

13. Delaš Aždajić M, Delaš I, Aždajić $S$, Štimac Grbić $D$, Vahčić N. Udio kuhinjske soli u kruhu Grada Zagreba [Salt content in bread from the city of Zagreb, Croatia, in Croatian]. Acta Med Croatica 2018;72:133-8.

14. Ugarčić-Hardi Ž, Dumančić G, Pitlik N, Koceva Komlenić D, Jukić, M, Kuleš A, Sabo M, Hardi J. The salt content in bakery products in Osječko-Baranjska County. In: UgarčićHardi Ž, editor. Abstract book of the $5^{\text {th }}$ International Congress and $7^{\text {th }}$ Croatian Congress of Cereal Technologists "Flour - Bread '09 “; Osijek, Croatia 2009. Osijek: Faculty of Food Technology Osijek; 2009.

15. Đurić J, Vitale K, Paradinović S, Jelaković B. Unos soli i arterijski tlak u općoj populaciji [Salt intake and arterial hypertension in general population, in Croatian]. Croat J Food Technol Biotechnol Nutr 2011;6:141-7.

16. Pucarin-Cvetković J, Kern J, Vuletić S. Regionalne karakteristike prehrane u Hrvatskoj [Regional features of Croatian nutrition, in Croatian]. Acta Med Croatica 2010;64:83-7.

17. Nielsen SS. Food Analysis Laboratory Manual. Food Science Texts Series. New York (NY): Springer Science+Business Media; 2010.

18. Pravilnik o žitaricama i proizvodima od žitarica [Ordinance on cereals and cereal products, in Croatian]. Narodne novine $81 / 2016$.

19. Silva V, Padrão P, Novela C, Damasceno A, Pinho O, Moreira $\mathrm{P}$, Lunet N. Sodium content of bread from bakeries and traditional markets in Maputo, Mozambique. Public Health Nutr 2015;18:610-4. doi: 10.1017/S1368980014000779

20. Saavedra-Garcia L, Sosa-Zevallos V, Diez-Canseco F, Miranda JJ, Bernabe-Ortiz A. Reducing salt in bread: a quasiexperimental feasibility study in a bakery in Lima, Peru. Public Health Nutr 2016;19:976-82. doi: 10.1017/ S1368980015001597

21. Grabež M, Rudić Grujić V, Petković V. Sodium content and the most important dietary sources of sodium in a sample of student population. Arh Hig Rada Toksikol 2017;68(Suppl 1):22-9.

22. Lazić V. Salt content in white bread in the Republic of Srpska. Scr Med 2017;48:24-9. doi: 10.18575/msrs.sm.s. 17.04

23. TNS Opinion \& Social. Special Eurobarometer 329/Wave 72.3 Health Determinants [displayed 20 August 2018]. Available at http://ec.europa.eu/commfrontoffice/ publicopinion/archives/ebs/ebs_329_sum_en.pdf

24. The Council of the European Union. Action to reduce population salt intake for better health - adoption of the conclusions. OJ (2010/C 305/04). [displayed 20 September 2019]. Available at http://publications.europa.eu/resource/ cellar/cf66a644-4ad3-48f6-8ddb-620238428aed.0020.02/ DOC_1

25. European Commission (EC). Survey on Members States' Implementation of the EU Salt Reduction Framework: directorate-general health and consumers [displayed 20 June 2018]. Available at https://ec.europa.eu/health//sites/health/ files/nutrition_physical_activity/docs/salt_report1_en.pdf 
26. Webster J, Trieu K, Dunford E, Hawkes C. Target salt 2025: a global overview of national programs to encourage the food industry to reduce salt in foods. Nutrients 2014;6:3274-87. doi: 10.3390/nu6083274

27. World Health Organization (WHO). Global Action Plan for the Prevention and Control of NCDs 2013-2020 [displayed 4 November 2018]. Available at https://www.who.int/nmh/ events/ncd_action_plan/en/

28. Ministry of Health. Strateški plan za smanjenje prekomjernog unosa kuhinjske soli u RH 2015-2019 [Strategic Plan for Reduction of Salt Intake, in Croatian]. [displayed 27 August 2018]. Available at https://www.hzjz.hr/wp-content/ uploads/2014/11/Strate $\%$ C $5 \%$ A 1 ki-plan-za-smanjenjeprekomjernog-unosa-kuhinjske-soli-u-RH-2015.-2019.pdf

29. McLaren L, Sumar N, Barberio AM, Trieu K, Lorenzetti DL, Tarasuk V, Webster J, Campbell NR. Population-level interventions in government jurisdictions for dietary sodium reduction. Cochrane Database Syst Rev 2016;9:CD010166. doi: 10.1002/14651858.CD010166.pub2

30. Laatikainen T, Pietinen P, Valsta L, Sundvall J, Reinivuo H, Tuomilehto J. Sodium in the Finnish diet: 20-year trends in urinary sodium excretion among the adult population. Eur J Clin Nutr 2006;60:965-70. doi: 10.1038/sj.ejcn.1602406

31. Slimani N, Deharveng G, Southgate DA, Biessy C, Chajès V, van Bakel MM, Boutron-Ruault MC, McTaggart A, Grioni S, Verkaik-Kloosterman J, Huybrechts I, Amiano P, Jenab M, Vignat J, Bouckaert K, Casagrande C, Ferrari P, Zourna P, Trichopoulou A, Wirfält E, Johansson G, Rohrmann S, Illner AK, Barricarte A, Rodríguez L, Touvier M, Niravong M, Mulligan A, Crowe F, Ocké MC, van der Schouw YT, Bendinelli B, Lauria C, Brustad M, Hjartåker A, Tjønneland A, Jensen AM, Riboli E, Bingham S. Contribution of highly industrially processed foods to the nutrient intakes and patterns of middle-aged populations in the European Prospective Investigation into Cancer and Nutrition study. Eur J Clin Nutr 2009;63:S206-25. doi: 10.1038/ejen.2009.82

32. Moubarac JC, Claro RM, Baraldi LG, Levy RB, Martins AP, Cannon G, Monteiro CA. International differences in cost and consumption of ready-to-consume food and drink products: United Kingdom and Brazil, 2008-2009. Glob Public Health 2013;8:845-56. doi: 10.1080/17441692.2013.796401

33. Bolhuis DP, Temme EH, Koeman FT, Noort MW, Kremer S, Janssen AM. A salt reduction of $50 \%$ in bread does not decrease bread consumption or increase sodium intake by the choice of sandwich fillings. J Nutr 2011;141:2249-55. doi: $10.3945 /$ jn. 111.141366

34. Nghiem N, Blakely T, Cobiac LJ, Cleghorn CL, Wilson N. The health gains and cost savings of dietary salt reduction interventions, with equity and age distributional aspects. BMC Public Health 2016;16:423. doi: 10.1186/s12889-0163102-1

35. Ugarčić Hardi Ž, Dumančić G, Koceva Komlenić D, Jukić, M. Količina soli u hrvatskim pekarskim proizvodima [Amount of salt in Croatian bakery products, in Croatian]. HČJZ 2010;6(21).

36. Ministry of Health, Republic of Croatia. Nacionalni program “Živjeti zdravo", 2015 [National Program "Living Healthy”, in Croatian] [displayed 25 August 2019]. Available at https:// zdravlje.gov.hr/UserDocsImages//Programi\%20i\%20 projekti $\% 20-\% 20$ ostali $\% 20$ programi//NP\%20 $\%$ C5\%BDivjeti\%20zdravo.pdf

\section{Udio kuhinjske soli u kruhu - presječno istraživanje u Zagrebu}

Smanjenje udjela kuhinjske soli u kruhu sastavni je dio nacionalne strategije smanjenja unosa soli u Republici Hrvatskoj. Cilj rada bio je analizirati udio kuhinjske soli u trima vrstama kruha, dostupnima u zagrebačkim pekarnicama. Prikupljeni su uzorci kruha iz 25 pekarnica malih obrtnika i od 5 industrijskih proizvođača pekarskih proizvoda na području Grada Zagreba. Udio kuhinjske soli u uzorcima kruha utvrđen je titracijskom metodom po Mohru, s prosječnom vrijednosti od $2,30 \pm 0,22 \mathrm{~g}$ na $100 \mathrm{~g}$ kruha. Dobivene vrijednosti gotovo su dvostruko veće od granične vrijednosti određene Pravilnikom o žitaricama i proizvodima od žitarica $(1,4 \%)$. Udio soli u svim analiziranim uzorcima bio je veći od preporučenih vrijednosti. Potrebno je daljnje usklađivanje zakonske regulative i prakse radi daljnjeg smanjenja dnevnog unosa soli i poboljšanja zdravlja stanovništva. 